\title{
DISASTER MEDICINE and
}

\section{PUBLIC HEALTH PREPAREDNESS}

An Official Publication of the Society for Disaster Medicine and Public Health, Inc

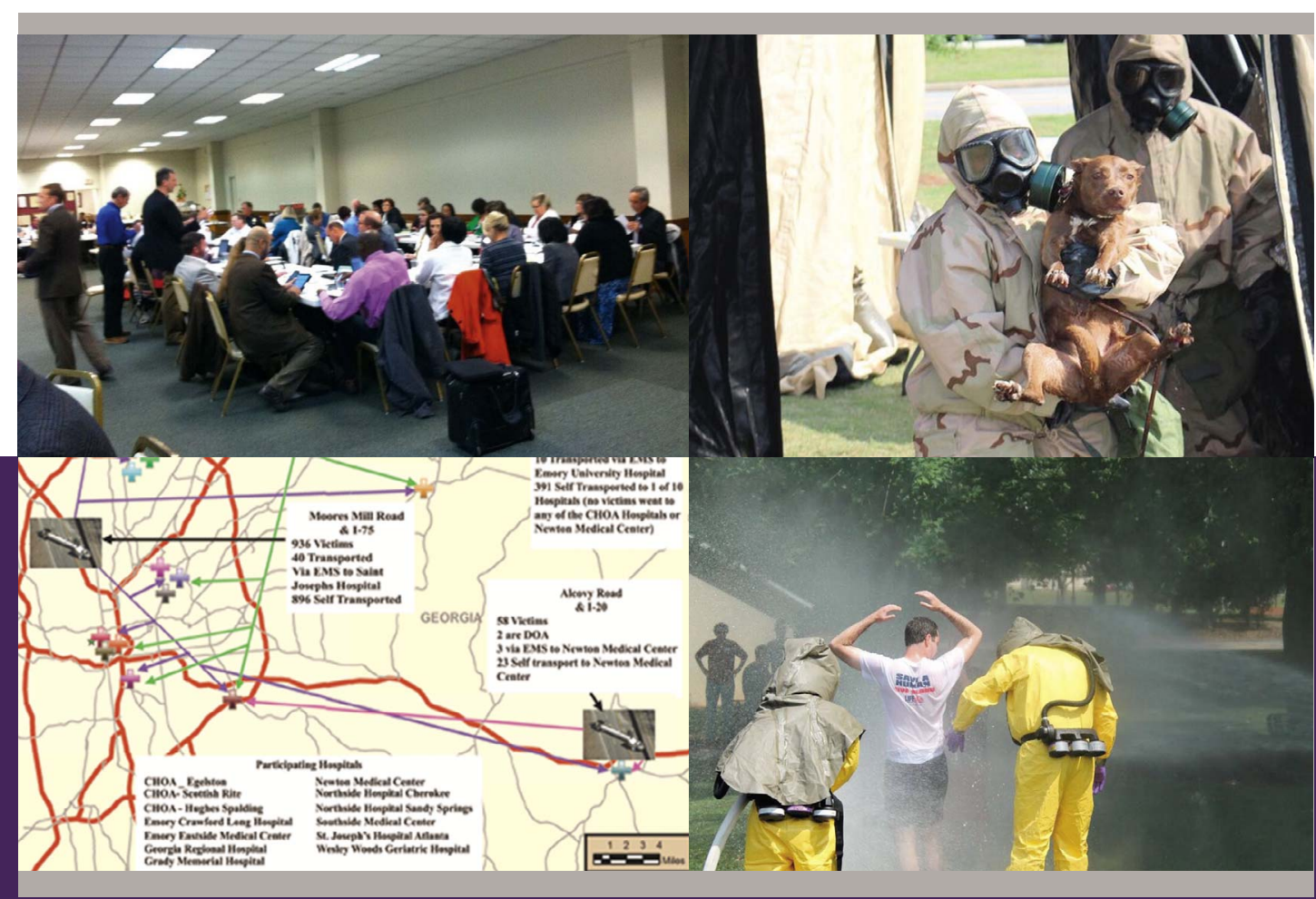

IN THIS ISSUE:

Nurses' Resilience in Disasters

Surge Capacity in Public Health Emergencies

Is There a Better Way to Provide Search and Rescue?

Nationwide Survey on Hospital Preparedness in Japan

SPECIAL SECTION: HEALTH CARE COALITIONS 

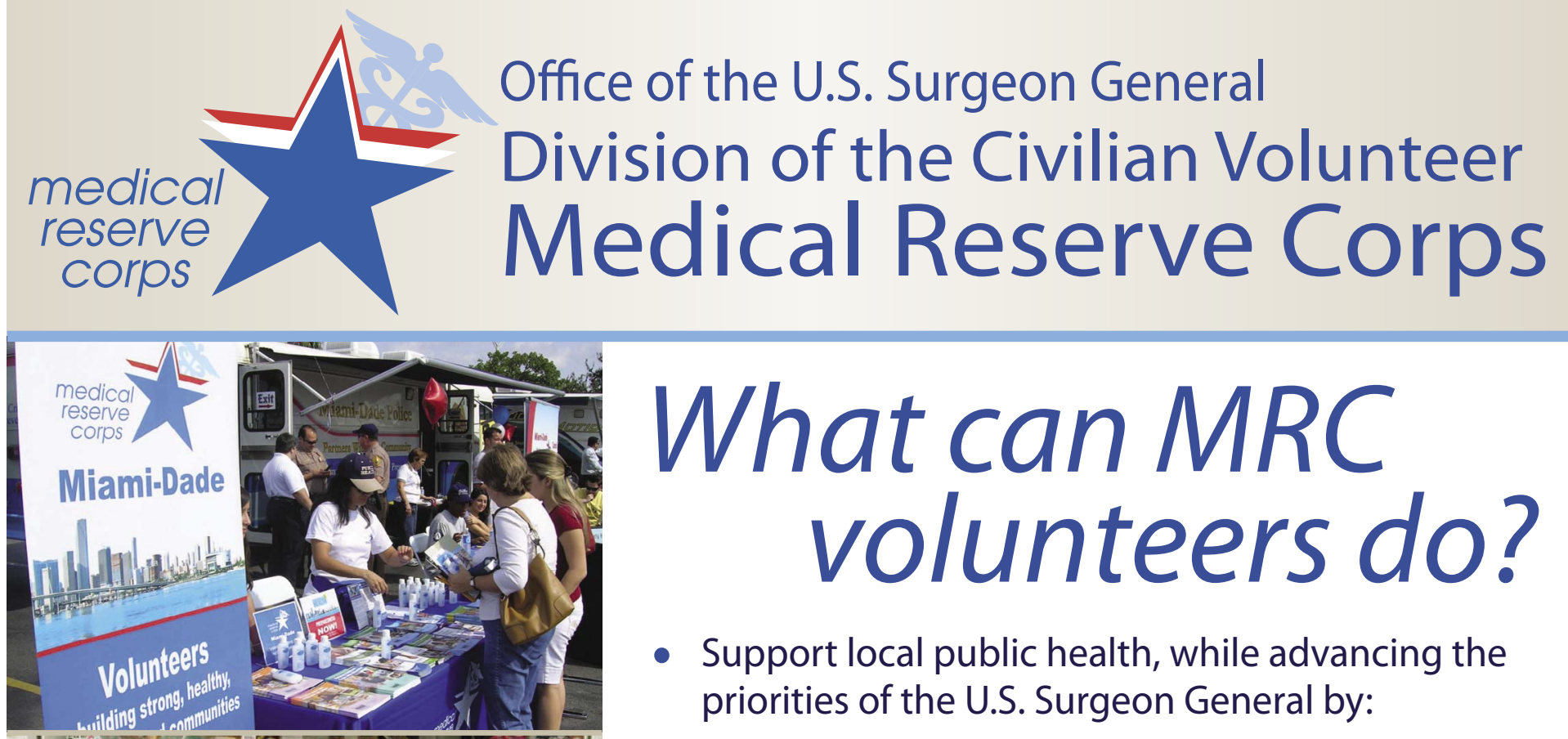

What can MRC

\section{volunteers do?}

- Support local public health, while advancing the priorities of the U.S. Surgeon General by:

$\checkmark$ Promoting disease prevention

$\checkmark$ Improving health literacy

$\checkmark$ Eliminating health disparities

$\checkmark$ Enhancing public health preparedness

- Assist local hospitals and health departments with surge personnel needs

- Participate in mass prophylaxis and vaccination exercises and community disaster drills

- Train with local emergency response partners

- And much more...

Connect with your local MRC unit today! www.MedicalReserveCorps.gov

The Tower Building

1101 Wootton Parkway, Suite 200

Rockville, MD 20852

240.453.2839 • MRCcontact@hhs.gov

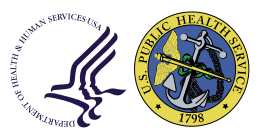

Volunteers Building Strong, Healthy, and Prepared Communities 


\section{Disaster Medicine and Public Health Preparedness}

Editor-in-Chief James J. James, MD, DrPH, MHA

Chief Executive Officer,

Society for Disaster Medicine and

Public Health, Inc., USA
Deputy Editor

David Markenson, MD, MBA

Chief Medical Officer

Sky Ridge Medical Center

Senior Fellow and Medical Director

Center for Disaster Medicine

New York Medical College

\section{Associate Editors}

Elizabeth Ablah, PhD, MPH

Associate Professor, University of Kansas-Wichita, School of Medicine

Daniel J. Barnett, MD, MPH

Assistant Professor,

Department of Environmental

Health Sciences, Johns Hopkins

Bloomberg School of Public Health

Charles W. Beadling, MD, FAAFP, IDHA, DMCC

Director. Center for Disaster and

Humanitarian Assistance Medicine

Uniformed Services University of the

Health Sciences

Rita V. Burke, PhD, MPH

Assistant Professor of Research Surgery and Preventive Medicine Pediatric Surgery, Children's Hospital Los Angeles

Laura J. Cavanaugh, MD, FAAP

Pediatrician, Private Practice, USA

Editorial Board

John Armstrong, MD, FACS

Associate Professor of Surgery,

USF Health, University of South Florida

Frederick M. Burkle Jr., MD, MPH, DTM, FAAP, FACEP

Senior Fellow, Harvard Humanitarian Initiative, Harvard School of Public Health

Cham E. Dallas, PhD

Director, Institute for Health Management in Mass Destruction Defense, University of Georgia \& Medical College of Georgia

Linda C. Degutis, DrPH, MSN

Director, National Center for Injury

Prevention and Control, Centers for Disease Control and Prevention

Lewis R. Goldfrank, MD

Herbert W. Adams Professor and Chair, Department of Emergency Medicine,

New York University

Medical Director, New York City Poison Center

John L. Hick, MD

Associate Professor of Emergency

Medicine, Hennepin County Medical

Center, University of Minnesota

James G. Hodge, Jr., JD, LLM

Lincoln Professor of Health Law and Ethics Director, Public Helath Law and Policy Program, Sandra Day O'Connor College of Law, Arizona State University
Jennifer L. Chan, MD, MPH

Assistant Professor, Department of Emergency Medicine, Northwestern Feinberg School of Medicine

Anat Gesser-Edelsburg, PhD

Head of Health Promotion Program, School of Public Health, Faculty of Social Welfare and Health Science, University of Haifa

Edbert B. Hsu, MD, MPH

Director of Training

Johns Hopkins Office of Critical Event

Preparedness and Response

Stephanie Kayden, MD, MPH

Director, International Emergency Medicine Fellowship, Brigham and Women's Hospital

Frederick C. Nucifora Jr., DO, PhD, MHS

Department of Psychiatry and Behavioral Science, Johns Hopkins University School of Medicine
Michael J. Reilly, DrPH, MPH, NREMT-P, CEM

Director, Center for Disaster Medicine Associate Professor of Environmental Health Science and Emergency Medicine New York Medical College

Rebecca Zukowski, PhD, RN

Associate Academic Dean and Nursing Division Chairperson, Mount Aloysius College

\section{Managing Editor}

Alice O'Donnell

HJF, National Center for Disaster Medicine and Public Health

Editorial support provided by the National Center for Disaster Medicine and Public Health

Copyeditor

Jennifer Holmes
Gabor Kelen, MD, FRCP(C), FACEP

Professor and Chair, Department of Emergency Medicine, Johns Hopkins University

Thomas D. Kirsch, MD, MPH, FACEP Associate Professor, Director of the Center for Refugee and Disaster Response, The Johns Hopkins School of Medicine/Bloomberg School of Public Health

William Lanier, MD

Professor of Anesthesiology, Mayo Clinic

Yasuhiro Otomo, MD, PhD

Director, Trauma and Acute Critical Care Medical Center Professor and Chairman, Tokyo Medical and Dental University Hospital of Medicine, Japan

Betty Pfefferbaum, MD, JD Chairman, Department of Psychiatry and Behavioral Sciences, University of Oklahoma Health Sciences Center

Irwin Redlener, MD

Director, National Center for Disaster Preparedness, Columbia University

Charles L. Rice, MD

President, Uniformed Services University of the Health Sciences
Hou Shi-ke, MD

Institute for Disaster \& Emergency Medicine of PAPF

Affiliated Hospital of Logistic University,

Tianjin City, China

W. Craig Vanderwagen, MD

RADM, US Public Health Service, retired Senior Partner, Martin, Blanck, and Associates

\section{Statistical Editors}

Guohua Li, MD, DrPH

M. Finster Chair in Anesthesiology and Epidemiology, Columbia University College of Physicians and Surgeons

Michael A. Stoto, PhD

Professor, Health Services Administration and Population Health, Georgetown University School of Nursing and Health Studies

Chair of Global Committee

Raymond E. Swienton, MD, FACEP

Co-director of EMS, Disaster Medicine and Homeland Security Section. University of Texas Southwestern

\section{Associate Board}

Erik Auf der Heide, MD, MPH, FACEP

Agency for Toxic Substances and Disease Registry,

US Department of Health and Human Services
Joseph A. Barbera, MD

Co-director, Institute for Crisi, Disaster, and Risk Mangagement, The George Washington University
Donna F. Barbisch, DrHA, MPH

Director, Institute for Global and Regional Readiness 


\section{Steven M. Becker, PhD}

Professor, College of Health Sciences Old Dominion University

Georges Benjamin, MD, FACP

Executive Director, American Public Health Association

John Brownstein, PhD

Associate Professor, Clinical and Public Health Informatics, Boston Children's Hospital

Arthur Cooper, MD, MS, FACS, FAAP, FCCM

Director of Trauma \& Pediatric Surgical Services, Harlem Hospital Center

Asha Devereaux, MD, MPH

Chair, American College of Chest Physicians Disaster Response Network

\section{Edward Eitzen, MD, MPH}

Senior Partner, Biodefense and Public Health Programs, Martin, Blanck and Associates

Mikael Eliasson, MD, PhD

Strategic Marketing Leader General Medicine, GE Healthcare

\section{Joshua Epstein, PhD}

Director, Center on Social and Economic Dynamics, The Brookings Institution

\section{J. Christopher Farmer, MD, FCCM}

Associate Dean, Critical Care Medicine, Mayo Clinic College of Medicine

\section{Richard Garfield, RN, DrPH}

Henrik H. Bendixen Professor of Clinical International Nursing, Columbia University

Jeffrey Hammond, MD, MPH

Clinical Professor of Surgery, Robert Wood Johnson Medical School

\section{Global Committee}

Michael Christian, MD, FRCP(C)

Department of Medicine, University of Toronto, Canada

\section{Herman Delooz, MD, PhD, FCCM, FCEM (dist)}

Research Group on Disaster Medicine. Free University of Brussels

\section{D.A. Henderson, MD, MPH}

Center for Biosecurity, University of

Pittsburgh Medical Center

David Joyner, MD

Vice Chairman/CMO, Salus Healthcare International

\section{David Lakey, MD}

Commissioner, Texas Department of State Health Services

\section{E. Brooke Lerner, PhD}

Department of Emergency Medicine, Medical College of Wisconsin

Jonathan Links, PhD

Director, Center for Public Health Preparedness, Johns Hopkins Bloomberg School of Public Health

Craig H. Llewellyn, MD, MPH, MSTMH, FACPM

Emeritus Professor of Military Medicine, Emergency Medicine, Preventative Medicine \& Surgery, Uniformed Services University School of Medicine

Darrell E. Lovins, DO, MPH, FACOFP Associate Dean, Clinical Sciences, William Carey University

Anthony Macintyre, MD

Visiting Associate Professor, Institute for Crisis, Disaster, and Risk Management, The George Washington University

\section{John Mutter, PhD}

Professor of International and Public Affairs, The Earth Institute at Columbia University

Kobi Peleg, PhD, MPH

Director, Israel National Center for Trauma and Emergency Medicine
Cheryl Peterson, RN, MSN

Senior Policy Fellow, American Nurses Association

\section{Steven J. Phillips, MD}

Director, Specialized Information Services, Associate Director, National Library of Medicine, US Department of Health and Human Services

\section{Louis Rowitz, PhD}

Professor, Community Health Sciences, School of Public Health, University of Illinois at Chicago

\section{Joseph Scanlon}

Professor Emeritus and Director Emergency Communications and Research Unit, Carleton University

\section{R. Tom Sizemore III, MD}

Principal Deputy Director, Office of Preparedness and Emergency Operations, US Department of Health and Human Services

\section{Robert Ursano, MD}

Professor/Chair, Department of Psychiatry, Uniformed Services University of the Health Sciences

\section{Jeb Weisman, PhD}

Director of Strategic Technologies, National Center for Disaster Preparedness, Columbia University

\section{Kevin Yeskey, MD}

Senior Advisor for Emergency Public Health, $M D B, \operatorname{lnc}$
Natalia Gudzenko, MD

Laboratory for Cancer Epidemiology, Research Center for Radiation Medicine, Ukraine

\section{Keqin Rao, MD, MPH}

Director, National Center for Health Statistics and Information, Ministry of Health. China

\section{Alessandra Rossodivita, MD EMDM}

San Raffaele Hospital Scientific Foundation, Milan, Italy

\section{Nobhojit Roy, MD, MPH}

Bhabha Atomic Research Center Hospital, Mumbai, India 


\section{Disaster Medicine and Public Health Preparedness}

DECEMBER 2015

Vol 9/No 6

On the Cover

599 Health Care Coalitions: The Georgia Approach Curtis Harris

Editorial

600 All For One, One For All

James J. James

Brief Reports

601 Resilience of Nurses in the Face of Disaster

Stephanie B. Turner

605 Cross-Sectional Study of the Impact of a Natural Disaster on the Delivery of Gynecologic Oncology Care Gizelka David-West, Fernanda Musa, Melissa K. Frey, Leslie Boyd, Bhavana Pothuri, John P. Curtin and Stephanie V. Blank

609 Ambulance Dispatches From Unaffected Areas After the Great East Japan Earthquake: Impact on Emergency Care in the Unaffected Areas

Akihito Hagihara, Daisuke Onozuka, Takashi Nagata, Takeru Abe, Manabu Hasegawa and Yoshihiro Nabeshima

614 Disaster Vulnerability of Hospitals: A Nationwide Surveillance in Japan

Sae Ochi, Shigeaki Kato, Kenichi Kobayashi and Yasuhiro Kanatani

619 Managing Community Resilience to Climate Extremes, Rapid Unsustainable Urbanization, Emergencies of Scarcity, and Biodiversity Crises by Use of a Disaster Risk Reduction Bank

Deon V. Canyon, Frederick M. Burkle, Jr and Rick Speare

Original Research

625 Exposure to the World Trade Center Disaster and 9/11-Related Post-Traumatic Stress Disorder and Household Disaster Preparedness

Lisa M. Gargano, Kimberly Caramanica, Sarah Sisco, Robert M. Brackbill and Steven D. Stellman

634 Assessing the Capacity of the US Health Care System to Use Additional Mechanical Ventilators

During a Large-Scale Public Health Emergency

Adebola Ajao, Scott V. Nystrom, Lisa M. Koonin, Anita Patel, David R. Howell, Prasith Baccam, Tim Lant, Eileen Malatino, Margaret Chamberlin and Martin I. Meltzer

Concepts in Disaster Medicine

642 Using Professional Organizations to Prepare the Behavioral Health Workforce to Respond to the Needs of Pediatric Populations Impacted by Health- Related Disasters: Guiding Principles and Challenges Ginny Sprang and Miriam Silman

650 Notes from Nepal: Is There a Better Way to Provide Search and Rescue? Kobi Peleg

Health Care Coalitions Special Section

653 Coalitions and Health Care Emergency Management Chad Priest and WC Vanderwagen

Editorials

654 Documentation of Coalitions Can Improve the Process, But Will it Lead to Better Outcomes? Craig Vanderwagen and Chad Priest

655 Perspectives From the Assistant Secretary for Preparedness and Response Nicole Lurie

Brief Report

657 Gulf Coast Resilience Coalition: An Evolved Collaborative Built on Shared Disaster Experiences, Response, and Future Preparedness

Tonya Cross Hansel, Howard J. Osofsky, Jennifer Langhinrichsen-Rohling, Anthony Speier, Tim Rehner, Joy D. Osofsky and Glenn Rohrer 
Original Research

666 Physician Emergency Preparedness: A National Poll of Physicians

Gillian K. SteelFisher, Robert J. Blendon, Amanda S. Brulé, Keri M. Lubell, Loretta Jackson Brown, Dahna Batts and Eran Ben-Porath

681 Medical Surge Capacity in Atlanta-Area Hospitals in Response to Tanker Truck Chemical Releases Curtis Harris, William Bell, Edward Rollor, Tawny Waltz, Pam Blackwell and Cham Dallas

690 Contributions of Health Care Coalitions to Preparedness and Resilience: Perspectives From Hospital Preparedness Program and Health Care Preparedness Coalitions Joie Acosta, Stefanie Howard, Anita Chandra, Danielle Varda, Sara Sprong and Lori Uscher-Pines

698 In Preparation or Response: Examining Health Care Coalitions Amid a Changing Economic and Political Landscape Mark E. Dornauer

704 Identifying Indirect Benefits of Federal Health Care Emergency Preparedness Grant Funding to Coalitions: A Content Analysis

Chad Priest and Benoit Stryckman

Concepts in Disaster Medicine

712 Transforming Health Care Coalitions From Hospitals to Whole of Community: Lessons Learned From Two Large Health Care Organizations

Scott Cormier, Michael Wargo and Walter Winslow

717 Optimizing Health Care Coalitions: Conceptual Frameworks and a Research Agenda

Nathaniel Hupert, Karen Biala, Tara Holland, Avi Baehr, Aisha Hasan and Melissa Harvey

Commentaries

724 The Office of Health Affairs and Our Role in Health Security

Kathryn Brinsfield and Sally Phillips

726 The US Department of Veterans Affairs and Sustainable Health Care Coalitions Aram Dobalian

728 Preparedness 3.0: Addressing the Future

Georges C. Benjamin

Letter to the Editor

730 MMRS Coalitions: Continuing Their Efforts

David N. Gerstner and Brandon P. Sobera

Thank You to Reviewers

731 Reviewers

\section{CONTACT INFORMATION}

\section{Editorial Office}

NCDMPH

11300 Rockville Pike, Suite 1000

Rockville, MD 20852

P: $240-833-4429$

E:dmphpjournal@gmail.com

Edited from the Offices of the National Center for Disaster Medicine and Public Health (NCDMPH) located at the Uniformed Services University of the Health Sciences (USUHS) under a cooperative enterprise agreement between USUHS and The Society for Disaster Medicine and Public Health. The views expressed in each article are those of the author and do not necessarily reflect the official policy or position of NCDMPH, USUHS, the Department of Defense, or the United States Government.

\section{Manuscript Submission and Instructions for Authors}

May be found online at http://mc.manuscriptcentral.com/dmp

\section{DMPHP Reprints \& Permissions}

\section{Article Reprints/E-prints Inquiry}

For use by commercial entities or educational institutions:

special_sales@cambridge.org

Permissions Inquiry

For rights and permissions inquiries, please visit www.cambridge.org/about-us/ rights-permissions

\section{Advertising}

For details about advertising rates and opportunities in Disaster Medicine and Public Health Preparedness, or to request a media pack, please contact M. J. Mrvica Associates, 2 West Taunton Avenue, Berlin, NJ 08009; Phone: 856-768-9360; Fax: 856-753-0064; Email: mjmrvica@mrvica.com.

Subscription Rates and Service

Subscription Information

Disaster Medicine and Public Health Preparedness (ISSN: 1935-7893; EISSN: 1938-744X) is published bi-monthly by Cambridge University Press, 32 Avenue of the Americas, New York, New York 10013. Copyright (C) 2015 by the Society for Disaster Medicine and Public Health, Inc.

\section{Annual Subscription Rates}

Annual institutional print and electronic subscription rates: US $\$ 600.00$ in the USA Canade and Mexico: UK £375.00 + VAT elsewhere Institutional electronic rates only: US $\$ 460.00 .00$ in the USA, Canada and Mexico; UK $£ 287.00$ + VAT elsewhere. Prices include surface postage and insurance.

Information on Disaster Medicine and Public Health Preparedness and all other Cambridge journals is available at http://www.cambridge.org/. Full text for this journal may be found at http:// journals.cambridge.org/dmp.

When citing this journal, please abbreviate as Disaster Med Public Health Preparedness.

Indexed in MEDLINE.

Disaster Medicine and Public Health Preparedness participates in the Health InterNetwork Access to Research Institute Initiative (HINARI), which provides free or very-low-cost online access to major journals in biomedical and related social sciences to local, nonprofit institutions in developing countries. Please visit www.who.int/hinari for more information.

Copyright @2015 Society for Disaster Medicine and Public Health, Inc.

All rights reserved. No part of this publication may be reproduced, in any form or by any means, electronic photocopying or otherwise, without permission in writing from Cambridge University Press, except when permission is obtained through a bona fide copyright clearinghouse, such as the Copyright Clearance through a bona fide copyright clearinghouse, such as the Copyright Clearance
Center (USA) or the Copyright Licensing Agency (UK). For further information please Center (USA) or the Copyright Licensing Agency (UK). For further information please
visit http://us.cambridge.org/information/rights/ or http://www.cambridge.org/uk/ information/rights/.

Periodicals postage paid at New York, NY, and additional mailing offices. Return Postage Guaranteed. Postmaster: Send address changes in the USA and Canada to: Disaster Medicine and Public Health Preparedness, Cambridge University Press, Journals Fulfillment Dept., 100 Brook Hill Drive, West Nyack, NY 10994-2133. 